\title{
Difference among Angiotensin-Converting Enzyme Inhibitors in Potentiating Effects on Bradykinin-Induced Microvascular Leakage in Guinea Pig Airways
}

\author{
Takashi Murata, Yukio Matsumoto, Tatsuo Kashida, Osamu Kaminuma, Kazuaki Naito*, \\ Katsuo Ikezawa and Kei Tsuzurahara \\ Pharmacological Research Laboratory, Tanabe Seiyaku Co., Ltd., 2-2-50 Kawagishi, Toda, Saitama 335, Japan \\ Received April 12, 1995 Accepted July 14, 1995
}

\begin{abstract}
We investigated the effect of imidapril, a novel angiotensin-converting enzyme (ACE) inhibitor, on augmentation of airway microvascular leakage induced by bradykinin (BK) and substance P (SP) in guinea pigs and compared it with those of enalapril and captopril. The three ACE inhibitors significantly potentiated BK- and SP-induced airway microvascular leakage in a dose-dependent manner. In spite of the compatible or higher ACE inhibitory activity of imidapril, its potentiating activity in BK-induced leakage was lower than those of enalapril and captopril both by single administration $(0.3-30 \mathrm{mg} / \mathrm{kg}, \mathrm{p} . \mathrm{o}$.) and repeated administration for eight days $(0.1-10 \mathrm{mg} / \mathrm{kg} / \mathrm{day}, \mathrm{p} .0$.$) . The potentiating activities of the three$ $\mathrm{ACE}$ inhibitors were suppressed by pretreatment with a $\mathrm{BK}_{2}$-receptor antagonist, but not by neurokinin 1 and neurokinin 2 antagonists, suggesting that neurokinins may not be involved in BK-induced leakage under the conditions used. On the other hand, the potentiating effect of imidapril in SP-induced leakage was weaker than those of enalapril and captopril only after single high doses. The present study shows that the $\mathrm{ACE}$ inhibitors have different activity in potentiation of the airway microvascular leakage induced by BK, which may be ascribable to the difference in their inhibition of BK hydrolysis. This evidence may partly explain the smaller incidence of dry cough induced by imidapril compared with other ACE inhibitors when clinically used as antihypertensive drugs.
\end{abstract}

Keywords: Angiotensin-converting enzyme inhibitor, Bradykinin, Vascular permeability, Plasma exudation, Airway (guinea pig)

Angiotensin-converting enzyme (ACE) inhibitors have been successfully used for the treatment of hypertension and heart failure. However, in recent years, it has been reported that they cause dry cough as one of their side effects with an incidence of $1-33 \%(1-6)$. The mechanism of dry cough induction by ACE inhibitors remains unclear, although it has been speculated that ACE inhibitors may inhibit enzymatic degradation of bradykinin (BK), which is thought to be one of the mediators of cough induction $(7,8)$. In fact, it is reported that ACE activity is high in the lung and vascular endothelial cells $(9,10)$. Additionally, BK is thought to release tachykinins such as substance $\mathrm{P}$ (SP) and neurokinin A (NKA) and prostaglandins (PGs). Tachykinin and $\mathrm{PGE}_{2}$ are supposed to enhance the cough reflex by stimulating the $\mathrm{C}$ fibers of the airway; and $\mathrm{PGF}_{2 \alpha}, \mathrm{PGD}_{2}$ and thromboxane

* To whom correspondence should be addressed.
$A_{2}$ cause bronchoconstriction (11-13). In clinical trials, it was reported that the threshold of cough induction challenged with capsaicin, a selective stimulant of $\mathrm{C}$ fibers, was lower in ACE-inhibitor-treated patients than in non-treated individuals $(14,15)$.

Imidapril is a novel ACE inhibitor of the non-sulfhydryl type (16) that possesses potent ACE inhibitory activity $(17,18)$ and antihypertensive activity in various animal models (19) and in patients $(20,21)$. In clinical trials, the episode of cough induced by imidapril is reported to be less than those induced by enalapril and captopril $(20,21)$. Imidapril is also reported to cause less incidence of cough and cough-like reflex in guinea pigs induced by citric acid and DMPP (1,1-dimethyl-4-phenylpiperazinium iodide), respectively (22). In the present study, we investigated the effect of imidapril and other ACE inhibitors on microvascular leakage in the guinea pig airway induced by BK and SP, which are thought to 
be possible mediators of cough induction.

\section{MATERIALS AND METHODS}

\section{Experimental animals}

Male Hartley guinea pigs (SLC, Hamamatsu), 5 weeks of age, weighing $350-450 \mathrm{~g}$ were used. They were kept in an animal room with controlled temperature $\left(23 \pm 1^{\circ} \mathrm{C}\right)$ and humidity $(55 \pm 5 \%)$.

\section{Airway microvascular leakage}

According to the method of Rogers et al. $(23,24)$, extravasation of Evans blue dye to the airway tissue was measured. This reaction has been reported to correlate well with extravasation of radiolabeled albumin in the skin (25) and airways (26). Imidapril $(0.3-100 \mathrm{mg} / \mathrm{kg}$ ), enalapril and captopril $(0.1-100 \mathrm{mg} / \mathrm{kg})$ were orally administered $2 \mathrm{hr}$ before $\mathrm{BK}$ or SP injection, and $\mathrm{BK}_{2}(1.2$ $\mathrm{mg} / \mathrm{kg})$-, neurokinin $1\left(\mathrm{NK}_{1}\right)(0.5 \mathrm{mg} / \mathrm{kg})-$ or $\mathrm{NK}_{2}(2$ $\mathrm{mg} / \mathrm{kg}$ )-antagonists were intravenously given immediately before BK injection. In some experiments, ACE inhibitors were given orally once a day for 8 days, and the last treatment was done $2 \mathrm{hr}$ before BK or SP injection. Then the animals were anesthetized with sodium pentobarbital ( $30 \mathrm{mg} / \mathrm{kg}$, i.p.), and the left jugular vein was cannulated to administer agents. Evans blue $(30 \mathrm{mg} / \mathrm{kg}$ ) and BK (3 $\mathrm{nmol} / \mathrm{kg})$ or SP $(1 \mathrm{nmol} / \mathrm{kg})$ were intravenously injected through the cannula over a period of $1 \mathrm{~min}$. After $5 \mathrm{~min}$, the animals were sacrificed by bleeding from the abdominal aorta. The thorax was opened and the lung was perfused with $50 \mathrm{ml}$ of saline through the right atrium. The airway organs were removed, and the connective tissue, vasculature and parenchyma were gently scraped off. The trachea, main bronchi and intrapulmonary airways were blotted and weighed. The dye extracted by placing the tissues for $22 \mathrm{hr}$ in $2 \mathrm{ml}$ of formamide at room temperature was quantified photometrically at $620 \mathrm{~nm}$ (VPR-35; Otsuka Electronics, Osaka) and was expressed as $\mu \mathrm{g} / \mathrm{g}$ wet tissue. ACE inhibitors were dissolved in $0.5 \%$ carboxymethylcellulose solution and BK- and NK-antagonists with physiological saline containing Tween 80 .

\section{Materials}

Imidapril ((4S)-1-methyl-3[(2S)-2-[N-((1S)-1-ethoxycarbonyl-3-phenylpropyl)amino]propionyl]-1-methyl-2-oxoimidazolidine-4-carboxylic acid hydrochloride), CP96,345 ( $\mathrm{NK}_{1}$ antagonist) and SR 48968 ( $\mathrm{NK}_{2}$ antagonist) were synthesized at the Research Laboratory of Applied Biochemistry, Tanabe Seiyaku, Co., Ltd. (Osaka). Other organic drugs and chemicals used in this experiment were as follows: enalapril and captopril (Sigma Co., St. Louis, MO, USA), BK, SP, D-Arg-[Hyp ${ }^{3}-\mathrm{Thi}^{5,8}$-D-Phe $\left.{ }^{7}\right]-\mathrm{BK}$ $\left(\mathrm{BK}_{2}\right.$ antagonist; Peptide Institute, Inc., Osaka), Evans blue (Tokyo-Kasei Co., Tokyo), formamide (Wako Pure Chemical Industries, Osaka), pentobarbital (Dainabot Co., Osaka), carboxymethylcellulose (Katayama Chemical Co., Osaka) and Tween 80 (Nacalai Tesque Inc. Kyoto).

\section{Statistical analyses}

Data are expressed as means with the standard error. Statistical analyses of the data were performed by analysis of variance (ANOVA) followed by Dunnett's method or the Tukey-Kramer method. When the $P$ value was less than 0.05 , the difference was considered to be significant

\section{RESULTS}

Effect of $B K$ and SP treatment on the airway microvascular leakage in guinea pigs and augmentation by enalapril

Intravenous injection of BK and SP caused a dose-dependent leakage of Evans blue in the trachea and main bronchi at doses above $3 \mathrm{nmol} / \mathrm{kg}$ and $30 \mathrm{pmol} / \mathrm{kg}$, respectively (data not shown).

In the preliminary experiments, pretreatment of guinea pigs with enalapril ( $100 \mathrm{mg} / \mathrm{kg}, \mathrm{p} . \mathrm{o}$.) $2 \mathrm{hr}$ before BK and SP injection showed significant augmentation of the microvascular leakage in the airway at agonist doses of 3 and $1 \mathrm{nmol} / \mathrm{kg}$, i.v., respectively (data not shown). Thus, the respective doses of the agonists were used in the following experiments. Neither imidapril, enalapril nor captopril, at $100 \mathrm{mg} / \mathrm{kg}$, p.o., induced Evans blue leakage in the trachea and main bronchi (data not shown),

\section{Effects of $A C E$ inhibitors on $B K$-induced microvascular} leakage in the guinea pig airway

All three ACE inhibitors dose-dependently augmented the BK ( $3 \mathrm{nmol} / \mathrm{kg}$, i.v.)-induced leakage (Fig. 1). Significant augmentation by captopril, enalapril and imidapril was observed at 1,3 and $30 \mathrm{mg} / \mathrm{kg}$ or more, respectively, in the trachea and at 3,3 and $30 \mathrm{mg} / \mathrm{kg}$ or more, respectively, in the main bronchi. As compared with the control group (vehicle treated: 8.1 $\pm 1.2 \mu \mathrm{g}$ Evans blue/g tissue), the potentiating activity of the leakage by imidapril, enalapril and captopril at $10 \mathrm{mg} / \mathrm{kg}$ was about $2.1(17.2 \pm 3.4 \mu \mathrm{g}$ Evans blue/g tissue), 4.5 (36.8 \pm 3.3$)$ and $4.4(35.4 \pm 5.6)$ times higher than the control, respectively, in the trachea. In the main bronchi (control $9.0 \pm 1.0)$, it was about $1.9(16.8 \pm 4.0 \mu \mathrm{g}$ Evans blue/g tissue), $6.1(55.1 \pm 2.9)$ and $6.2(55.4 \pm 5.6)$ times higher, respectively, at the same dose. By multiple treatments for 8 days with the ACE inhibitors, a dose-dependent augmentation of BK-induced microvascular leakage was also observed both in the trachea and main bronchi (Fig. 2). The augmentation by imidapril was less than those by 


\section{A) trachea}

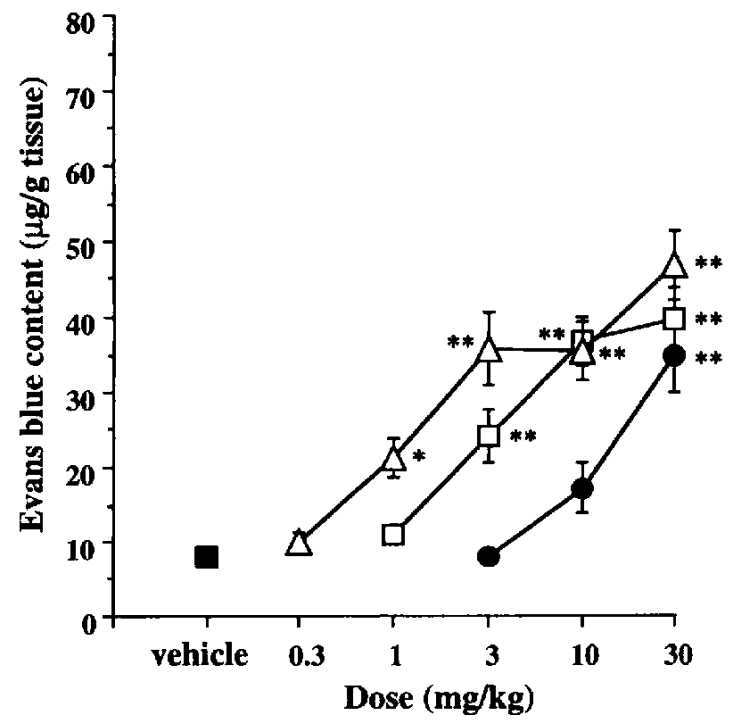

\section{B) main bronchi}

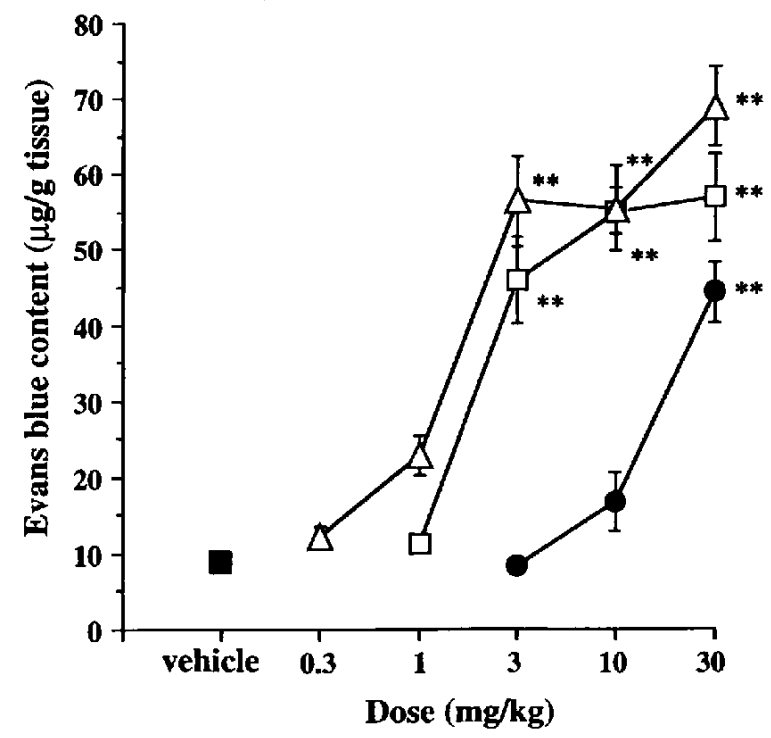

Fig. 1. Effects of ACE inhibitors on bradykinin (3 nmol/ $\mathrm{kg}$ )-induced airway microvascular leakage in the trachea (A) and main bronchi (B) of the guinea pigs. Imidapril $(O)$, enalapril $(\square)$, captopril $(\triangle)$ and the vehicle $(0.5 \% \mathrm{CMC})(\square)$ were orally administered $2 \mathrm{hr}$ before the injection of bradykinin. Each point represents the mean \pm S.E.M. of 8 to 11 animals: ${ }^{*} \mathrm{P}<0.05,{ }^{* *} \mathrm{P}<0.01$, compared with the vehicle group (Dunnett's method).

enalapril and captopril. The augmentation of BK-induced microvascular leakage by multiple treatments was observed at lower doses than that for the single treatment.

\section{A) trachea}

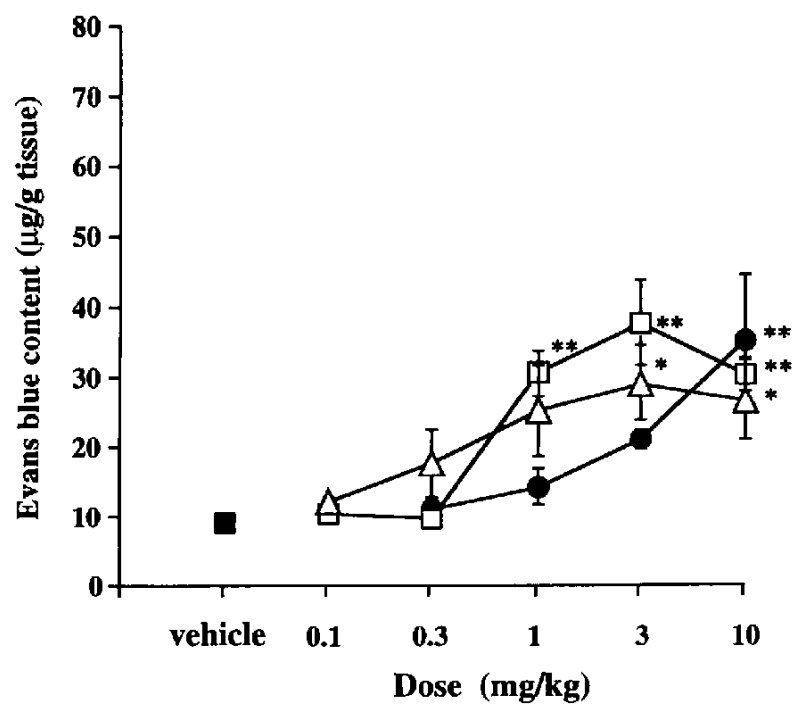

B) main bronchi

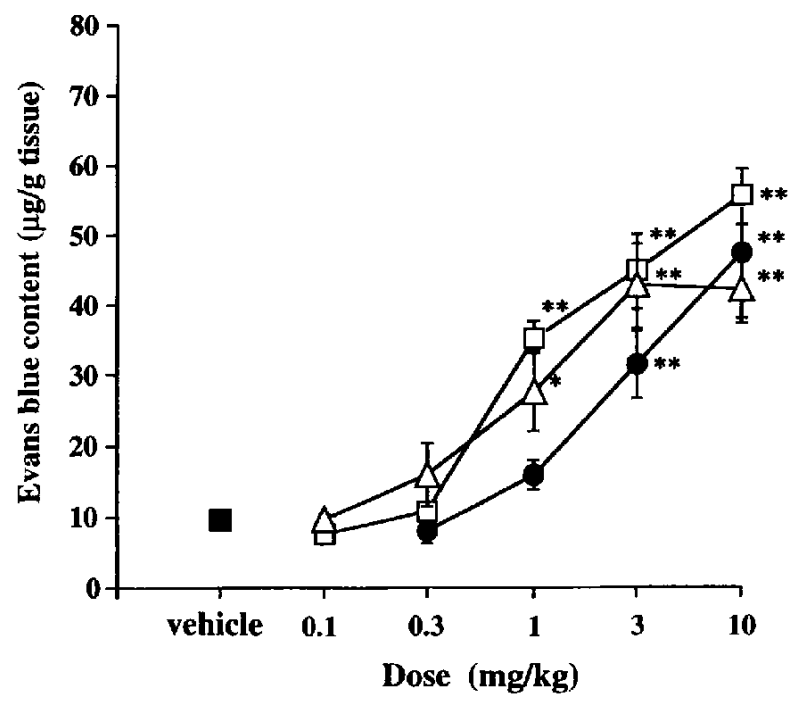

Fig. 2. Effects of ACE inhibitors on bradykinin ( $3 \mathrm{nmol} / \mathrm{kg}$ )-induced airway microvascular leakage in the trachea (A) and main bronchi (B) of the guinea pigs. Imidapril (O), enalapril $(\square)$, captopril $(\triangle)$ and the vehicle $(0.5 \% \mathrm{CMC})(\square)$ were orally administered once a day for 8 days. The final dosing was done $2 \mathrm{hr}$ before the injection of bradykinin. Each point represents the mean \pm S.E.M. of 8 to 9 animals: ${ }^{*} \mathbf{P}<0.05,{ }^{* *} \mathbf{P}<0.01$, compared with the vehicle group (Dunnett's method).

Effects of a $B K_{2}$ antagonist on augmentation of $B K$-induced microvascular leakage by $A C E$ inhibitors

Pretreatment with a $\mathrm{BK}_{2}$ antagonist, D-Arg-[Hyp ${ }^{3}$ $\left.\mathrm{Thi}^{5,8}{ }^{5} \mathrm{D}-\mathrm{Phe} \mathrm{e}^{7}\right]$-BK $(1.2 \mathrm{mg} / \mathrm{kg}$, i.v. $)$, just before BK injection significantly reversed the augmentation of micro- 
Table 1. Effect of $\mathrm{BK}_{2}$ antagonist (D-Arg- $\left[\mathrm{Hyp}^{3}, \mathrm{Thi}^{\mathrm{S}, 8}, \mathrm{D}-\mathrm{Phe} \mathrm{7}^{7}\right]-\mathrm{BK}$ ) on microvascular leakage induced by bradykinin in airway tissues of the guinea pigs

\begin{tabular}{|c|c|c|c|c|}
\hline \multirow{2}{*}{ Treatment } & \multirow{2}{*}{ n } & \multicolumn{3}{|c|}{ Evans blue dye content ( $\mu \mathrm{g} / \mathrm{g}$ wet tissue) } \\
\hline & & trachea & main bronchi & I.P.A. \\
\hline \multicolumn{5}{|l|}{ Control } \\
\hline $0.5 \% \mathrm{CMC}$ & 5 & $7.7 \pm 2.3$ & $8.0 \pm 0.8$ & $3.0 \pm 0.4$ \\
\hline \multicolumn{5}{|l|}{ Imidapril } \\
\hline $10 \mathrm{mg} / \mathrm{kg}+$ saline & 6 & $14.0 \pm 3.1$ & $12.1 \pm 2.0$ & $5.9 \pm 1.2$ \\
\hline $10 \mathrm{mg} / \mathrm{kg}+\mathrm{BK}_{2}$ antagonist $(1.2 \mathrm{mg} / \mathrm{kg})$ & 6 & $5.9 \pm 0.6$ & $9.2 \pm 0.9$ & $3.1 \pm 0.5$ \\
\hline $30 \mathrm{mg} / \mathrm{kg}+$ saline & 5 & $46.9 \pm 3.7^{* *}$ & $45.8 \pm 2.7^{* *}$ & $27.0 \pm 1.7^{* *}$ \\
\hline $30 \mathrm{mg} / \mathrm{kg}+\mathrm{BK}_{2}$ antagonist $(1.2 \mathrm{mg} / \mathrm{kg})$ & 5 & $13.3 \pm 3.6^{++}$ & $20.6 \pm 3.7^{++}$ & $10.3 \pm 3.0^{++}$ \\
\hline \multicolumn{5}{|l|}{ Enalapril } \\
\hline $3 \mathrm{mg} / \mathrm{kg}+$ saline & 4 & $22.8 \pm 7.4$ & $32.4 \pm 11.8^{* *}$ & $12.0 \pm 3.6$ \\
\hline $3 \mathrm{mg} / \mathrm{kg}+\mathrm{BK}_{2}$ antagonist $(1.2 \mathrm{mg} / \mathrm{kg})$ & 4 & $4.2 \pm 0.4$ & $7.5 \pm 0.7$ & $3.9 \pm 1.0$ \\
\hline $10 \mathrm{mg} / \mathrm{kg}+$ saline & 3 & $42.4 \pm 7.4^{* *}$ & $37.5 \pm 6.1^{* *}$ & $25.2 \pm 4.0^{* *}$ \\
\hline $10 \mathrm{mg} / \mathrm{kg}+\mathrm{BK}_{2}$ antagonist $(1.2 \mathrm{mg} / \mathrm{kg})$ & 4 & $11.7 \pm 1.1^{++}$ & $17.8 \pm 1.2$ & $11.0 \pm 1.7^{++}$ \\
\hline $30 \mathrm{mg} / \mathrm{kg}+$ saline & 4 & $45.4 \pm 2.3^{* *}$ & $55.9 \pm 9.3^{* *}$ & $24.9 \pm 1.3^{* * *}$ \\
\hline $30 \mathrm{mg} / \mathrm{kg}+\mathrm{BK}_{2}$ antagonist $(1.2 \mathrm{mg} / \mathrm{kg})$ & 5 & $21.3 \pm 4.0^{+}$ & $26.6 \pm 3.7^{*,+}$ & $14.4 \pm 3.5^{* * *}$ \\
\hline \multicolumn{5}{|l|}{ Captopril } \\
\hline $10 \mathrm{mg} / \mathrm{kg}+$ saline & 5 & $47.1 \pm 3.4^{* *}$ & $34.3 \pm 2.0^{* *}$ & $20.2 \pm 2.7^{* *}$ \\
\hline $10 \mathrm{mg} / \mathrm{kg}+\mathrm{BK}_{2}$ antagonist $(1.2 \mathrm{mg} / \mathrm{kg})$ & 5 & $12.3 \pm 3.6^{1+}$ & $15.3 \pm 2.9^{++}$ & $7.3 \pm 1.6^{++}$ \\
\hline $30 \mathrm{mg} / \mathrm{kg}+$ saline & 5 & $50.9 \pm 3.8^{* *}$ & $50.1 \pm 4.3^{* *}$ & $29.4 \pm 2.6^{* *}$ \\
\hline $30 \mathrm{mg} / \mathrm{kg}+\mathrm{BK}_{2}$ antagonist $(1.2 \mathrm{mg} / \mathrm{kg})$ & 5 & $9.3 \pm 1.4^{++}$ & $13.1 \pm 2.1^{++}$ & $7.4 \pm 1.4$ \\
\hline
\end{tabular}

ACE inhibitors were orally administered $2 \mathrm{hr}$ before $\mathrm{BK}$ injection. The $\mathrm{BK}_{2}$ antagonist D-Arg-[Hyp $\left.{ }^{3}, \mathrm{Thi}^{5,8}, \mathrm{D}-\mathrm{Phe}^{7}\right]$ $\mathrm{BK}$ ) was given i.v. to the animal immediately before administration of BK $(3 \mathrm{nmol} / \mathrm{kg}$, i.v. $)$. Each value is a mean \pm S.E.M. Statistical significance: ${ }^{*} \mathrm{P}<0.05,{ }^{* *} \mathrm{P}<0.01$, compared with the control value (Dunnett's method); ${ }^{+} \mathrm{P}<0.05,{ }^{++} \mathrm{P}<0.01$, compared with the ACE inhibitor group at the same dose (Tukey-Kramer method). I.P.A.: intrapulmonary airway.

vascular leakage in the trachea, main bronchi and intrapulmonary airway induced by the ACE inhibitors that were given $2 \mathrm{hr}$ prior to BK injection (Table 1). Airway microvascular leakage potentiations by imidapril $(10$ $\mathrm{mg} / \mathrm{kg}$ ) and enalapril $(3 \mathrm{mg} / \mathrm{kg})$ were almost completely inhibited by $\mathrm{BK}_{2}$ antagonist at all airway levels. At 10 $\mathrm{mg} / \mathrm{kg}$, the potentiating effect of captopril was also inhibited by more than $70 \%$ in all the airway tissues. At high doses of each inhibitor $(30 \mathrm{mg} / \mathrm{kg})$, it was also inhibited by more than $50-90 \%$. However, no remarkable difference in the effect of $\mathrm{BK}_{2}$ antagonist on Evans blue leakage was observed among the ACE inhibitors tested in all the airway tissues.

Effects of $\mathrm{NK}_{I^{-}}$and $\mathrm{NK}_{2}$-antagonist on augmentation of $B K$-induced microvascular leakage by $A C E$ inhibitors

Neither the $\mathrm{NK}_{1}$ antagonist CP-96,345 $(0.5 \mathrm{mg} / \mathrm{kg}$, i.v.) nor the $\mathrm{NK}_{2}$ antagonist SR $48968(2 \mathrm{mg} / \mathrm{kg}$, i.v.) given just before BK injection affected the augmentation of Evans blue leakage in the airway tissues induced by the ACE inhibitors (Table 2). Co-administration of $\mathrm{NK}_{1}(0.5$ $\mathrm{mg} / \mathrm{kg}$, i.v.)- and $\mathrm{NK}_{2}(2 \mathrm{mg} / \mathrm{kg}$, i.v.)-antagonists did not show any effects either (data not shown).

Effects of ACE inhibitors on SP-induced microvascular leakage in the guinea pig airway

Enalapril dose-dependently augmented SP $(1 \mathrm{nmol} / \mathrm{kg}$, i.v.)-induced microvascular leakage in the trachea and main bronchi only at high doses of 30-100 and 100 $\mathrm{mg} / \mathrm{kg}$, p.o., respectively (Fig. 3). Captopril 10-100 $\mathrm{mg} / \mathrm{kg}$, p.o., enhanced the leakage only in the trachea. In contrast, imidapril $(10-100 \mathrm{mg} / \mathrm{kg}$, p.o.) did not augment leakage in either the trachea or the main bronchi. When the ACE inhibitors $(10-100 \mathrm{mg} / \mathrm{kg} /$ day, p.o.) were given for 8 days, however, no significant augmentation of leakage was observed (Fig. 4).

\section{DISCUSSION}

Recently, ACE inhibitors have been reported to induce dry cough as a side effect in spite of their usefulness as antihypertensive drugs. ACE inhibitor-induced dry cough is independent of its antihypertensive and vasodilating effects (27) and does not correlate with serum ACE activ- 
Table 2. Effects of the $\mathrm{NK}_{1}$ antagonist $\mathrm{CP}-96,345$ and the $\mathrm{NK}_{2}$ antagonist SR 48968 on microvascular leakage induced by bradykinin in airway tissues of the guinea pig

\begin{tabular}{|c|c|c|c|c|}
\hline \multirow{2}{*}{ Treatment } & \multirow{2}{*}{$\mathrm{n}$} & \multicolumn{3}{|c|}{ Evans blue dye content ( $\mu \mathrm{g} / \mathrm{g}$ wet tissue) } \\
\hline & & trachea & main bronchi & I.P.A. \\
\hline \multicolumn{5}{|l|}{ Control } \\
\hline $0.5 \% \mathrm{CMC}$ & 8 & $8.8 \pm 1.8$ & $5.9 \pm 1.3$ & $3.6 \pm 0.7$ \\
\hline \multicolumn{5}{|l|}{ Imidapril } \\
\hline $10 \mathrm{mg} / \mathrm{kg}+$ saline & 6 & $17.1 \pm 4.5$ & $15.9 \pm 4.1$ & $9.8 \pm 2.7$ \\
\hline $10 \mathrm{mg} / \mathrm{kg}+\mathrm{CP}-96,345(0.5 \mathrm{mg} / \mathrm{kg})$ & 6 & $19.1 \pm 3.7$ & $13.7 \pm 2.6$ & $7.3 \pm 1.3$ \\
\hline $10 \mathrm{mg} / \mathrm{kg}+\mathrm{SR} 48968(2 \mathrm{mg} / \mathrm{kg})$ & 6 & $11.0 \pm 3.7$ & $14.9 \pm 4.1$ & $7.7 \pm 2.1$ \\
\hline $30 \mathrm{mg} / \mathrm{kg}+$ saline & 6 & $37.9 \pm 6.0^{* *}$ & $47.7 \pm 4.5^{* *}$ & $31.5 \pm 5.1^{* *}$ \\
\hline $30 \mathrm{mg} / \mathrm{kg}+\mathrm{CP}-96,345(0.5 \mathrm{mg} / \mathrm{kg})$ & 6 & $47.0 \pm 4.4^{* *}$ & $51.1 \pm 7.0^{* *}$ & $33.7 \pm 4.8^{* *}$ \\
\hline $30 \mathrm{mg} / \mathrm{kg}+\mathrm{SR} 48968(2 \mathrm{mg} / \mathrm{kg})$ & 6 & $35.7 \pm 2.5^{* *}$ & $40.0 \pm 6.4^{* *}$ & $26.1 \pm 3.5^{* *}$ \\
\hline \multicolumn{5}{|l|}{ Enalapril } \\
\hline $3 \mathrm{mg} / \mathrm{kg}+$ saline & 6 & $21.7 \pm 5.9$ & $30.4 \pm 6.7^{* * *}$ & $15.1 \pm 3.7$ \\
\hline $3 \mathrm{mg} / \mathrm{kg}+\mathrm{CP}-96,345(0.5 \mathrm{mg} / \mathrm{kg})$ & 6 & $26.3 \pm 5.2$ & $29.1 \pm 5.3^{* * *}$ & $21.3 \pm 3.7^{* * *}$ \\
\hline $3 \mathrm{mg} / \mathrm{kg}+\mathrm{SR} 48968(2 \mathrm{mg} / \mathrm{kg})$ & 6 & $25.1 \pm 3.5$ & $43.4 \pm 8.4^{* *}$ & $20.0 \pm 4.2^{* *}$ \\
\hline $10 \mathrm{mg} / \mathrm{kg}+$ saline & 6 & $34.8 \pm 6.6^{* *}$ & $40.6 \pm 3.9^{* *}$ & $26.4 \pm 3.1^{* *}$ \\
\hline $10 \mathrm{mg} / \mathrm{kg}+\mathrm{CP}-96,345(0.5 \mathrm{mg} / \mathrm{kg})$ & 7 & $41.8 \pm 3.1^{* *}$ & $37.8 \pm 3.4^{* *}$ & $31.6 \pm 2.8^{* *}$ \\
\hline $10 \mathrm{mg} / \mathrm{kg}+\mathrm{SR} 48968(2 \mathrm{mg} / \mathrm{kg})$ & 6 & $44.0 \pm 4.6^{* *}$ & $47.8 \pm 4.1^{* *}$ & $34.0 \pm 4.8^{* *}$ \\
\hline \multicolumn{5}{|l|}{ Captopril } \\
\hline $3 \mathrm{mg} / \mathrm{kg}+$ saline & 6 & $43.9 \pm 3.7^{* * *}$ & $42.3 \pm 2.8^{* *}$ & $28.5 \pm 3.3^{* * *}$ \\
\hline $3 \mathrm{mg} / \mathrm{kg}+\mathrm{CP}-96,345(0.5 \mathrm{mg} / \mathrm{kg})$ & 6 & $44.3 \pm 5.2^{* *}$ & $32.3 \pm 6.7^{* *}$ & $25.2 \pm 2.5^{* * *}$ \\
\hline $3 \mathrm{mg} / \mathrm{kg}+\mathrm{SR} 48968(2 \mathrm{mg} / \mathrm{kg})$ & 6 & $34.2 \pm 5.7^{* *}$ & $44.3 \pm 3.0^{* *}$ & $29.9 \pm 2.7^{* *}$ \\
\hline $10 \mathrm{mg} / \mathrm{kg}+$ saline & 7 & $43.5 \pm 6.7^{* *}$ & $42.6 \pm 4.9^{* *}$ & $34.4 \pm 4.1^{* *}$ \\
\hline $10 \mathrm{mg} / \mathrm{kg}+\mathrm{CP}-96,345(0.5 \mathrm{mg} / \mathrm{kg})$ & 7 & $46.4 \pm 5.7^{* *}$ & $49.2 \pm 6.2^{* *}$ & $35.0 \pm 4.7^{* *}$ \\
\hline $10 \mathrm{mg} / \mathrm{kg}+\mathrm{SR} 48968(2 \mathrm{mg} / \mathrm{kg})$ & 5 & $54.5 \pm 4.0^{* *}$ & $56.2 \pm 4.3^{* *}$ & $33.1 \pm 2.3^{* *}$ \\
\hline
\end{tabular}

ACE inhibitors were orally administered $2 \mathrm{hr}$ before $\mathrm{BK}$ injection. $\mathrm{NK}_{1}$ antagonist (CP-96,345) and $\mathrm{NK}_{2}$ antagonist (SR 48968) was given i.v. to the animal immediately before administration of BK ( $3 \mathrm{nmol} / \mathrm{kg}$, i.v.). Each value is a mean \pm S.E.M. Statistical significance: ${ }^{* * P}<0.01$, compared with the control value (Dunnett's method). I.P.A.: intrapulmonary airway.

ity in patients (6). However, from the fact that angiotensin II-receptor antagonists that are being developed as antihypertensive agents do not induce cough in their clinical trials (28), ACE inhibition itself is thought to be one of the main mechanisms of dry cough induction. Clinically, the incidence of dry cough varies among individual inhibitors, being smaller for imidapril compared with enalapril and captopril $(4,20,21)$.

In the present study, the influences of ACE inhibitors on biological activities of $\mathrm{BK}$ and SP were investigated in guinea pig airway. These peptides are possible mediators of cough induction and are also the substrates of ACE (kininase II) $(7,8)$. Augmentation of BK-induced microvascular leakage by imidapril was smaller than that by enalapril and captopril both by single (Fig. 1) and multiple treatment (Fig. 2). The main pharmacological effects of $\mathrm{BK}$ in the airway are bronchoconstriction and enhancement of vascular permeability, and it is reported that the $\mathrm{BK}_{2}$ receptor is involved in these responses (29).
This augmentation of BK-induced microvascular leakage by $\mathrm{ACE}$ inhibitors was blocked by the selective $\mathrm{BK}_{2}$ antagonist D-Arg-[Hyp $\left.{ }^{3}-\mathrm{Thi}^{5,8}-\mathrm{D}-\mathrm{Phe}^{7}\right]-\mathrm{BK}$ (Table 1), and without ACE inhibitors, microvascular leakage was not observed by the amount of BK used (data not shown). These lines of evidence suggest that $\mathrm{ACE}$ inhibitors suppress the breakdown of BK by ACE in the airway and the extent of breakdown is different among the ACE inhibitors. It has been demonstrated that enalapril significantly increased the blood BK levels, whereas imidapril did not have any influence on it in guinea pigs (personal communication, T. Miyata et al.). Regarding the augmentation of BK-induced hypotension which may influence the vascular permeability, imidapril was almost as potent as enalapril and less active than captopril in the rat (19). In SP-induced microvascular leakage, similar augmentation was observed. However, the extent was weak in imidapril compared with other ACE inhibitors only after single high doses (Fig. 3). The effects of multiple treatment with 


\section{A) trachea}

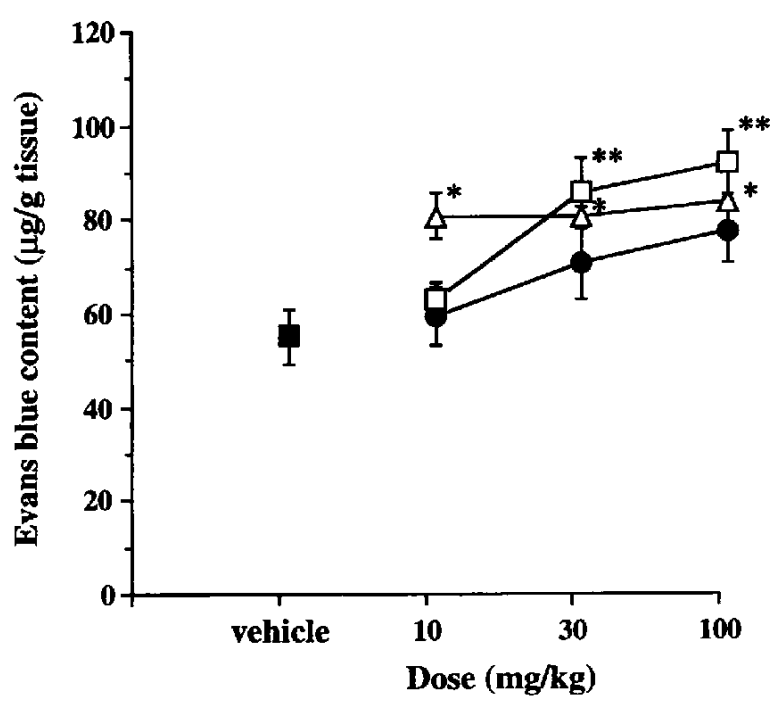

\section{B) main bronchi}

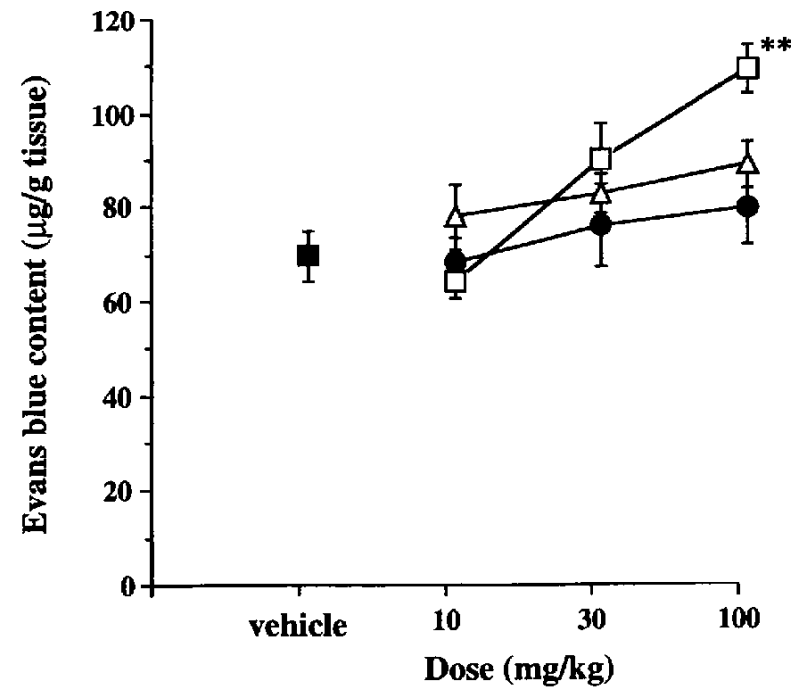

Fig. 3. Effects of ACE inhibitors on substance $P(1 \mathrm{nmol} / \mathrm{kg})$-induced airway microvascular leakage in the trachea (A) and main bronchi $(B)$ of the guinea pigs. Imidapril $(O)$, enalapril $(\square)$, captopril $(\triangle)$ and the vehicle $(0.5 \% \mathrm{CMC})(\square)$ were orally administered $2 \mathrm{hr}$ before the injection of substance $P$. Each point represents the mean \pm S.E.M. of 7 to 11 animals: ${ }^{*} \mathrm{P}<0.05,{ }^{* *} \mathrm{P}<0.01$, compared with the vehicle group (Dunnett's method).

the three ACE inhibitors were almost the same (Fig. 4). Vascular leakage induced by BK was more sensitive to ACE inhibitors than that induced by SP. One of the explanations of the results is substrate specificity of $\mathrm{BK}$ degrading enzymes, namely ACE and neutral endopeptidase (NEP). According to Turner et al. (30), SP has more than 1000 times higher affinity to NEP in com-

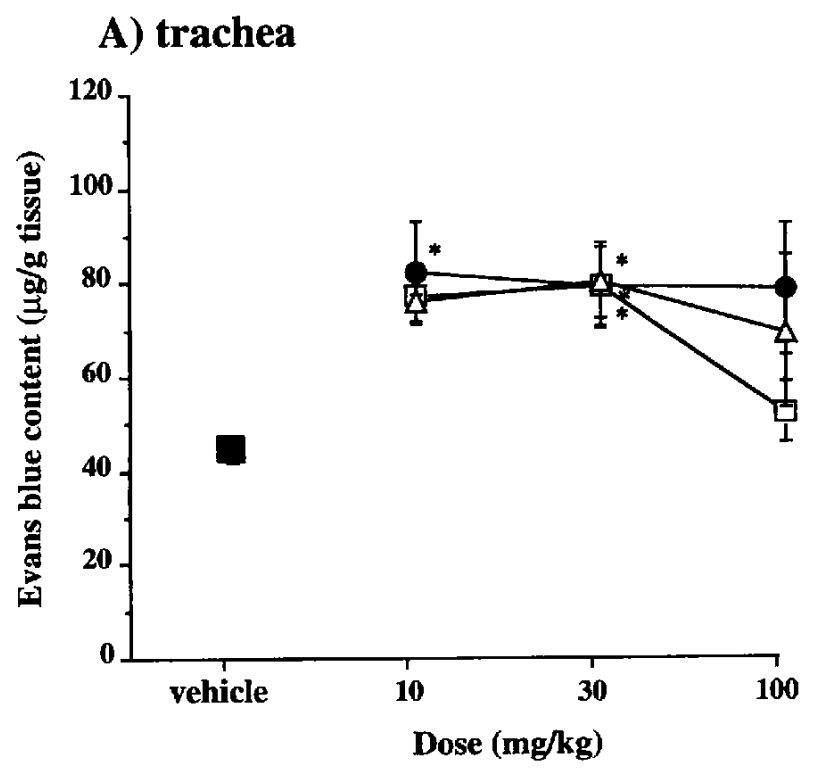

B) main bronchi

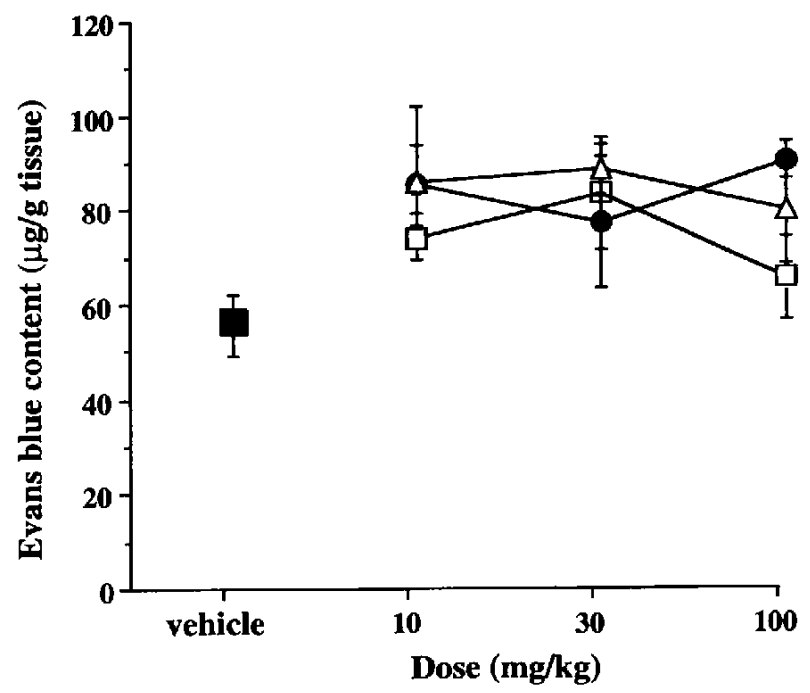

Fig. 4. Effects of $\mathrm{ACE}$ inhibitors on substance $P(1 \mathrm{nmol} / \mathrm{kg})$-induced airway microvascular leakage in the trachea (A) and main bronchi (B) of the guinea pigs. Imidapril (O), enalapril $(\square)$, captopril $(\triangle)$ and the vehicle $(0.5 \% \mathrm{CMC})(\square)$ were orally administered once a day for 8 days. The final dosing was done $2 \mathrm{hr}$ before the injection of substance $P$. Each point represents the mean \pm S.E.M. of 2 to 4 animals: ${ }^{*} P<0.05$, compared with the vehicle group (Dunnett's method).

parison with $\mathrm{ACE}$, while $\mathrm{BK}$ has about 10 times higher affinity to NEP. From the results observed by us and others described above, it is considered that the degradation of $\mathrm{BK}$ is more extensively inhibited by ACE inhibitors than in the case of SP.

Wei et al. $(31,32)$ have reported that $\mathrm{ACE}$ has two 
active centers ( $\mathrm{N}$ and $\mathrm{C}$ domains) in its molecule and that the affinities of ACE inhibitors to each domain are different among the inhibitors. It is interesting to know whether the difference in the affinities correlates with the difference in the degree of augmentation of BK-induced vascular leakage and with the incidence of dry cough induction after treatment with ACE inhibitors. Because imidapril has lower activities in these two responses than enalapril and captopril in spite of its compatible or higher inhibitory activity of ACE (17-20). Okamura et al. (33) studied the activity of ACE inhibitors from the viewpoint of substrate specificity using the isolated dog mesenteric artery and vein. They demonstrated that imidaprilat showed relatively lower inhibitory activity on BK degradation than enalaprilat at the concentrations that exhibit equal inhibiting activity, where imidaprilat and enalaprilat were active metabolites of imidapril and enalapril, respectively. These facts may partly explain our present results in the BK-induced vascular leakage experiment.

We also investigated the effects of NK receptor antagonists in the augmentation of the ACE inhibitors. It is reported that $\mathrm{BK}$ is a potent stimulant of the sensory nerve (C-fiber) of the airways (34) and releases tachykinins $(35,36)$ and that augmentation of BK-induced vascular permeability is inhibited by $\mathrm{NK}_{1}$-receptor antagonists $(37,38)$. The present results showed, however, that neither the $\mathrm{NK}_{1}$ antagonist nor the $\mathrm{NK}_{2}$ antagonist had any effect on augmenting activities of the ACE inhibitors (Table 2). Therefore, it is supposed that tachykinins are not involved in the potentiating effect by the $\mathrm{ACE}$ inhibitors in our protocol. Though the reason for this discrepancy is unclear, the differences in the route of administration $(36,37)$, the dosage of BK or estimating systems (bronchoconstriction, vascular leakage) may be involved.

In conclusion, when the ACE inhibitors were given, augmentation of the BK-induced vascular leakage was smaller for imidapril compared with enalapril and captopril. This difference could be ascribed to the difference in the effects of ACE inhibitors on BK degradation by ACE (kininase II) or other peptidylic enzymes. Therefore, we suppose that imidapril is a more selective inhibitor of angiotensin I conversion compared with BK degradation than enalapril and captopril, and that BK is thought to be one of the main mediators involved in dry cough formation induced in patients by the treatment with ACE inhibitors. The above evidence may partly explain the smaller incidence of dry cough induced by imidapril compared with other ACE inhibitors.

\section{Acknowledgments}

We thank Dr. T. Oh-ishi and Dr. T. Iwasaki for their encouragement and advice. Thanks are also due to Dr. K. Kikuta for his helpful support.

\section{REFERENCES}

1 Sesoko S and Kaneko Y: Cough associated with the use of captopril. Arch Intern Med 145, 1524 (1985)

2 Andrejak M, Andrejak MT and Osterman G: Enalapril, captopril, and cough. Arch Intern Med 148, 249 (1988)

3 Karpman L: Cough from ACE inhibitors. Am Heart J 116, 1658 (1988)

4 Town GI, Hallwright GP, Maling TJB and O'Donnell TV: Angiotensin converting enzyme inhibitors and cough. N Z Med J 100, $161-163$ (1987)

5 Coulter DM and Edwards IR: Cough associated with captopril and enalapril. Br Med J 294, 1521 - 1523 (1987)

6 McEwan JR, Choudry N, Street R and Fuller RW: Change in cough reflex after treatment with enalapril and ramipril. Br Med J 299, 13 - 16 (1989)

7 Dusser DJ, Nadel JA, Sekizawa K, Graf PD and Borson DB: Neutral endopeptidase and angiotensin converting enzyme inhibitors potentiate kinin-induced contraction of ferret trachea. J Pharmacol Exp Ther 244, 531-536 (1988)

8 Fuller RW, Dixon CMS, Cuss FMC and Barnes PJ: Bradykinin-induced bronchoconstriction in humans: Mode of action. Am Rev Respir Dis 135, 176-180 (1987)

9 Cushman DW and Cheung HS: Concentrations of angiotensinconverting enzyme in tissues of the rat. Biochim Biophys Acta 250, 261-265 (1971)

10 Caldwell PRB, Seegal BC, Hsu KC, Das M and Soffer RL: Angiotensin converting enzyme: Vascular endothelial localization. Science 191, 1050-1051 (1976)

11 Coleridge HM, Coleridge JCG, Ginzel KH, Baker DG, Banzett $\mathrm{RB}$ and Morrison MA: Stimulation of 'irritant' receptors and afferent C-fibers in the lungs by prostaglandins. Nature 264 , $451-453$ (1976)

12 Bhoola $\mathrm{KD}$, Figueroa $\mathrm{CD}$ and Worthy $\mathrm{K}$ : Bioregulation of kinins: Kallikreins, kininogens, and kininases. Pharmacol Rev 44, 1- 80 (1992)

13 Roberts AM, Schultz HD, Green JF, Armstrong DJ, Kaufman MP, Coleridge HM and Coleridge JCG: Reflex tracheal contraction evoked in dogs by bronchodilator prostaglandins $E_{2}$ and $\mathrm{I}_{2}$. J Appl Physiol 58, 1823-1831 (1985)

14 Fuller RW and Choudry NB: Increased cough reflex associated with angiotensin converting enzyme inhibitor cough. Br Med J 295, 1025-1026 (1987)

15 Morice AH, Lowry R, Brown MJ and Higenbottam T: Angiotensin-converting enzyme and the cough reflex. Lancet 2 , $1116-1118$ (1987)

16 Hayashi K, Nunami K, Kato J, Yoneda N, Kubo M, Ochiai T and Ishida R: Studies on angiotensin converting enzyme inhibitors. 4. Synthesis and angiotensin converting enzyme inhibitory activities of 3-acyl-1-alkyl-2-oxoimidazolidine-4-carboxylic acid derivatives. J Med Chem 32, 289-297 (1989)

17 Sugaya T, Minobe S, Taniguchi T, Hashimoto Y, Kubo M and Watanabe $T$ : Studies on angiotensin I converting enzyme (ACE) inhibitory effect of imidapril (I). Inhibition of various tissue ACEs in vitro. Folia Pharmacol Jpn 100, 39-45 (1992) (Abstr in English)

18 Hashimoto $\mathrm{Y}$, Kubo M, Sugaya T, Minobe S, Watanabe T, Yamamura $M$ and Matsuoka $Y$ : Studies on angiotensin I converting enzyme (ACE): Inhibitory effect of imidapril, a novel ACE inhibitor (II). Inhibition of various tissue ACEs ex vivo. 
Folia Pharmacol Jpn 104, 51-61 (1994) (Abstr in English)

19 Kubo M, Kato J, Ochiai T and Ishida R: Pharmacological studies on (4S)-1-methyl-3-\{(2S)-2-[N-((1S)-1-ethoxycarbonyl-3phenylpropyl)amino]propionyl $\}$-2-oxoimidazolidine-4-carboxylic acid hydrochloride (TA-6366), a new ACE inhibitor: I. ACE inhibitory and anti-hypertensive activities. Jpn J Pharmacol 53, 201-210 (1990)

20 Saruta $T$, Omae $T$, Kuramochi M, Iimura O, Yoshinaga K, Abe K, Ishii M, Watanabe T, Takeda T, Ito K, Kokubo T, Fujishima M, Arakawa $\mathrm{K}$ and Nakashima $\mathrm{M}$ : Clinical usefulness of imidapril hydrochloride (ACE/TA-6366) on essential hypertension - A double-blind comparative study with enalapril maleate-. Rinsho-Iyaku (J Clin Ther Med) 8, 661-697 (1992) (Abstr in English)

21 Saruta T, Omae T, Kuramochi M, Iimura O, Yoshinaga K, Abe K, Ishii M, Watanabe T, Takeda T, Itou K, Kokubo T, Arakawa $\mathrm{K}$ and Fujishima $\mathrm{M}$ : Efficacy and safety of imidapril (ACE/TA-6366), angiotensin I converting enzyme inhibitor, in monotherapy on essential hypertension -Multiclinic open trial-. Rinsho-Iyaku (J Clin Ther Med) 7, 2485-2504 (1991) (Abstr in English)

22 Sumikawa H, Ogiku N, Hashimoto $\mathrm{Y}$, Kudo $\mathrm{Y}$ and Ishida R: Study on cough-potentiating effect of imidapril, a new ACE inhibitor, in guinea pigs. Jpn Pharmacol Ther 20, 13-19 (1992) (Abstr in English)

23 Rogers DF, Belvisi MG, Aursudkij B, Evans TW and Barnes PJ: Effects and interactions of sensory neuropeptides on airway microvascular leakage in guinea pigs. $\mathrm{Br} \mathrm{J}$ Pharmacol 95, $1109-1116$ (1988)

24 Rogers DF, Dijk S and Barnes PJ: Bradykinin-induced plasma exudation in guinea pig airways: involvement of platelet activating factor. Br J Pharmacol 101, 739-745 (1990)

25 Udaka K, Takeuchi $\mathrm{Y}$ and Movat HZ: Simple method for quantitation of enhanced vascular permeability. Proc Soc Exp Biol Med 133, 1384-1387 (1970)

26 Rogers DF, Boschetto P and Barnes PJ: Plasma exudation: correlation between Evans blue dye and radiolabeled albumin in guinea pig airways in vivo. J Pharmacol Methods 21, 309-315 (1989)

27 Lindgren BR: New aspects on inflammatory reactions and cough following inhibition of angiotensin converting enzyme. Acta Physiol Scand Supp 573, 1-60 (1988)
28 Saruta T: Angiotensin receptor antagonist and its role in clinical medicine. Saishin-Igaku 47, 102- 107 (1992) (Abstr in English)

29 Ichinose $\mathbf{M}$ and Barnes PJ: Bradykinin-induced airway microvascular leakage and bronchoconstriction are mediated via a bradykinin $B_{2}$ receptor. Am Rev Respir Dis 142, 1104-1107 (1990)

30 Turner AJ, Matsas R and Kenny AJ: Commentary. Are there neuropeptide-specific peptidases? Biochem Pharmacol 34, $1347-1356$ (1985)

31 Wei L, Alhenc-Gelas F, Corvol $\mathbf{P}$ and Clauser E: The two homologous domains of human angiotensin I-converting enzyme are both catalytically active. J Biol Chem 266, 9002-9008 (1991)

32 Wei L, Clauser E, Alhenc-Gelas F and Corvol P: The two homologous domains of human angiotensin I-converting enzyme interact differently with competitive inhibitors. J Biol Chem 267, 13398 - 13405 (1992)

33 Okamura T, Kitamura Y, Kimura T and Toda N: Comparison of selective actions of imidaprilat and enalaprilat on the response to angiotensin I and bradykinin in isolated dog blood vessels. Pharmacometrics 46, 427-436 (1993) (Abstr in English)

34 Kaufman MP, Coleridge HM, Coleridge JCG and Baker DG: Bradykinin stimulates afferent vagal $\mathrm{C}$-fibers in intrapulmonary airways of dogs. J Appl Physiol 48, 511-517 (1980)

35 Saria A, Martling CR, Yan Z, Theodorsson-Norheim E, Gamse $\mathrm{R}$ and Lundberg JM: Release of multiple tachykinins from capsaicin-sensitive sensory nerves in the lung by bradykinin, histamine, dimethylphenyl piperazinium, and vagal nerve stimulation. Am Rev Respir Dis 137, 1330-1335 (1988)

36 Ichinose $\mathrm{M}$, Belvisi $\mathrm{MG}$ and Barnes $\mathrm{PJ}$ : Bradykinin-induced bronchoconstriction in guinea pig in vivo: Role of neural mechanisms. J Pharmacol Exp Ther 253, 594- 599 (1990)

37 Sakamoto T, Barnes PJ and Chung KF: Effect of CP-96,345, a non-peptide $\mathrm{NK}_{1}$ receptor antagonist, against substance $P$-, bradykinin- and allergen-induced airway microvascular leakage and bronchoconstriction in the guinea pig. Eur J Pharmacol 231, 31-38 (1993)

38 Nakajima N, Ichinose $M$, Takahashi $T$, Yamauchi $H$, Igarashi A, Miura $\mathbf{M}$, Inoue $\mathbf{H}$, Takishima $\mathbf{T}$ and Shirato $\mathbf{K}$ : Bradykinin-induced airway inflammation: Contribution of sensory neuropeptides differs according to airway site. Am J Respir Crit Care Med 149, 694-698 (1994) 